\title{
EDUKASI PEMANFAATAN TANAMAN SEBAGAI APOTEK HIDUP MEWUJUDKAN MASYARAKAT SEHAT DAN PRODUKTIF
}

\author{
Rahmatia Thahir ${ }^{*}$, Muhammad Wajdi ${ }^{2}$, Anisa $^{3}$, Nurdiyanti $^{4}$, \\ Nurul Fadhilah ${ }^{5}$, Nurul Magfirah ${ }^{6}$ \\ ${ }_{1 *}^{*} 2,3,4,5,6$ Universitas Muhammadiyah Makassar, Makassar, Indonesia \\ 1*rahmatiah.thahir@unismuh.ac.id \\ 2muh.wajdi@unismuh.ac.id \\ 3anisa@unismuh.ac.id \\ 4nurdiyanti@unismuh.ac.id \\ 5nurul.fadhilah@unismuh.ac.id \\ 6nurul.magfirah@unismuh.ac.id
}

\begin{abstract}
Abstrak:
Desa pacceke adalah salah satu desa di kecamatan soppeng riaja kabupaten barru, Sulawesi selatan. Sebagain besar masyarakat desa pacceke berprofesi sebagai petani, namun masih banyak masyarakat yang belum mengenal dan memanfaatkan tanaman sebagai apotek hidup. Tujuan dari kegiatan ini adalah mengedukasi masyarakat tentang manfaat tanaman sebagai apotek hidup untuk mewujudkan masyarakat sehat dan produktif yang dimulai dari diri sendri dan keluarga. Kegiatan PkM dilaksanakan pada hari senin, tanggal 5 maret 2018 di Gedung pertemuan desa pacceke. Kegiatan ini dirangkaikan dengan kegiatan pandawa yang dilaksanakan oleh himabio Pendidikan biologi Universitas Muhammadiyah Makassar. Penyampaian materi dilakukan dalam bentuk penyampaian langsung dan pembagian brosur kepada masyarakat. Tahap kegiatan terdiri dari 3 tahap yaitu tahap persiapan, tahap pelaksanaan, dan tahap evaluasi.
\end{abstract}

Kata Kunci: Tanaman, apotek hidup, masyarakat sehat

\section{Pendahuluan}

Indonesia merupakan salah satu negara dengan beranekaragaman tanaman yang dapat tumbuh. Tanaman tidak hanya bermanfaat sebagai bahan makanan ataupun sebagai hiasan. Tetapi tanaman juga banyak bermanfaat untuk mepnyembuhan dan pengobatan. Kemampuan menyembuhkan dan efek positif dari beberapa tanaman sebagai obat telah lama diketahui, jauh sebelum ilmuan menemukan berbagai obat-obatan dengan bahan kimia. Tanaman obat ini juga dapat dibudidayakan sendiri di rumah atau biasa disebut apotek hidup. Apotek hidup adalah kegiatan budidaya tanaman obat di halaman rumah atau pekarangan sebagai antisipasi pencegahan maupun mengobati secara mandiri menggunakan tanaman obat yang ada (Nugraha \& Agustiningsih, 2015). Mayarakat yang berada dipedesaan memanfaatkan 
tumbuhan sebagai obat tradisional. Pengetahuan tentang tumbuhan obat dan pengembangannya yang bersumber dari hutan dan pekarangan seharusnya mendapat perhatian besar. Untuk menunjang kelestarian lingkungan hidup dan menjaga agar tumbuhan obat tetap ada maka perlu dikembangkan kegiatan budidaya tumbuhan obat (Dewantari et al., 2018).

Indonesia dikenal sebagai gudangnya tanaman obat sehingga mendapat julukan live laboratory (Nurniswati, 2015). Sekitar 30.000 jenis tanaman obat yang dimiliki Indonesia. Dengan kekayaan flora tersebut, tentu Indonesia memiliki potensi untuk mengembangkan produk herbal yang kualitasnya setara dengan obat modern. Namun sumber daya alam tersebut baru sekitar 1200 spesies tanaman obat yang dimanfaatkan sebagai obat tradisional. Dibidang tanaman obat, Indonesia dikenal sebagai salah satu negara yang memiliki keanekaragaman hayati terbesar kedua setelah Brazil, sehingga sangat potensial dalam mengembangkan tanaman obat yang berbasis pada tanaman obat milik kita sendiri. Indonesia kaya akan aneka ragam tanaman yang bermanfaat bagi Kesehatan. ribuan spesies tumbuhan dapat dimanfaatkan sebagai bahan baku obat, oleh karena itu budidaya tanaman obat dalam bentuk apotek hidup memiliki potensi yang sangat besar untuk dikembangkan.

Adanya kenyataan bahwa tingkat kebutuhan masyarakat terhadap pengobatan semakin meningkat, sementara taraf kehidupan sebagian masyarakat masih dibawah rata-rata. Maka dari itu pengobatan dengan bahan alam yang ekonomis merupakan solusi yang baik untuk menanggulangi masalah tersebut. Dengan Kembali maraknya Gerakan Kembali kea lam (back to nature), kecenderungan penggunaan bahan obat alam atau herbal di dunia semakin meningkat. Dilatarbelakangi oleh perubahan lingkungan, pola hidup manusia, dan perkembangan pola penyakit. Obat yang berasal dari bahan alam memiliki efek samping lebih rendah dibandingkan obat-obatan kimia, karena efek obat herbal bersifat alamiah (Nurniswati, 2015).

Berdasarkan hasil observasi tim $\mathrm{PkM}$ di lokasi mitra yaitu desa pacceke kecamatan soppeng riaja kabupaten barru, Sulawesi selatan diperoleh informasi bahwa banyak masyarakat memiliki Riwayat penyakit seperti hipertensi, reumatik, dan asam urat. Riwayat tersebut bisa muncul disebabkan oleh pola hidup yang kurang baik dari masyarakat. Sebagai informasi juga dari kepala desa pacceke bahwa sebagian besar masyarakat memiliki mata pencaharian sebagai petani. Berangkat ke sawah atau kebun pada pagi hari dan pulang saat sore hari. Sawah masyarakat berjarak puluhan kilometer dari rumah mereka, dan saat tiba disawah maka kaki atau sebagain tubuh akan terendam air sepanjang hari, kurang istirahat, kurang minum, makan makanan yang berulang kali dipanasi, dan mandi pada malam hari. Kebiasaan ini bisa memicu 
munculnya penyakit, reumatik, asam urat, maag, hipertensi, dan penyakit lainnya. Dengan mengingat bahaya penyakit jika terjadi komplikasi dan resiko pengobatan kimia jangka panjang. Keberadaan puskesmas pembantu (Pustu) tidak dioperasionalkan dengan baik karena pegawai yang bertugas jarang berada di tempat. Sedangkan rumah sakit berada di kota yang jaraknya sangat jauh dari desa pacceke. Sehingga keberadaan apotek hidup ini dipandang sangat bermanfaat bagi Kesehatan masyarakat.

Walaupun masyarakat pacceke sebagai besar berprofesi sebagai petani, namun masih ada masyarakat yang belum mengenal tanaman obat atau apotek hidup. Padahal apotek hidup perlu dikembangkan karena tidak hanya sebagai obat alternatif yang disediakan gratis oleh alam semesta tetapi juga sebagai rempah atau bahan tambahan masakan atau makanan, seperti tanaman jahe, kunyit, sirih, dan lain-lain.

Berdasarkan uraian di atas, maka tim pelaksana $\mathrm{PkM}$ memberikan solusi dengan melaksanakan edukasi kepada masyarakat tentang pemanfaat tanaman sebagai apotek hidup yang sangat penting bagi Kesehatan masyarakat dan membentuk masyarakat lebih produktif. Karena tanaman obat ini bisa juga dipasarkan dan bentuk jamu atau berupa bumbu masakan. Edukasi dalam pemanfaat tanaman sebagai apotek hidup dapat dilakukan dengan model pendekatan pemberdayaan masyarakat (empowernment) (Basuki et al., 2020) yaitu membantu masyarakat dalam mengetahui dan mengatasi masalahnya sendiri, sehingga akan terbentuk kesadaran sendiri dalam menerapkannya.

Adapun tujuan pelaksanaan kegiatan $\mathrm{PkM}$ ini adalah mengedukasi masyarakat tentang pemanfaatan tanaman sebagai apotek hidup untuk mewujudkan masyarakat sehat dan produktif yang dimulai dari diri sendiri dan keluarga. Luaran yang dihasilkan dari pelaksanaan PkM ini adalah peningkatan kualitas Kesehatan dan produktifitas masyarakat dengan pemanfaatan tanaman sebagai apotek hidup.

\section{Metode Pelaksanaan}

Kegiatan pengabdian kepada masyarakat ini memberikan edukasi kepada masyarakat tentang pemanfaatan tanaman sebagai apotek hidup mewujudkan masyarakat sehat dan produktif di desa pacceke kecamatan soppeng riaja kabupaten barru. Kegiatan ini terdiri dari 3 tahap, yaitu 1. Tahap persiapan, 2. Tahan pelaksanaan, dan 3. Tahap evaluasi.

Adapun rincian tahap-tahap kegiatan pengabdian kepada masyarakat $(\mathrm{PkM})$ ini sebagai berikut:

1. Tahap persiapan. Tahap persiapan ini dilakukan sebelum pelaksanaan kegiatan $\mathrm{PkM}$ di 
desa pacceke, tahapannya antara lain: a. pengumpulan informasi yang dilakukan oleh tim $\mathrm{PkM}$ di lokasi mitra. Informasi tersebut berupa kegiatan keseharian masyarakat, pola hidup, Riwayat penyakit, dan tanaman yang biasa dijadikan obat jika sakit; b. koordinasi lapangan. Koordinasi lapangan dilakukan antara tim pelaksana $\mathrm{PkM}$ dan kepala desa pecceke terkait materi yang akan disampaikan saat penyuluhan, dan penentuan jadwal dan tempat kegiatan $\mathrm{PkM}$.

2. Tahap pelaksanaan. Kegiatan PkM dilaksanakan pada tanggal 5 maret 2018, bertempat di gedung pertemuan desa pacceke pada pukul 08.00 - 12.00 WITA. Kegiatan edukasi dengan penyuluhan dilaksanakan dengan pemberian materi dengan presentasi dan pembagian brosur kepada masyarakat. Pemberian materi disampaikan langsung oleh tim dosen pelaksana PkM dan brosur dibagikan oleh mahasiswa kepada masyarakat. Adapun jumlah peserta yang mengikuti kegiatan $\mathrm{PkM}$ sebanyak 44 orang.

3. Tahap evaluasi. Setelah kegiatan penyuluhan selesai, selanjutnya melaksanakan tahap evaluasi yang dilakukan oleh tim pelaksana dan mahasiswa Universitas Muhammadiyah Makassar. Tim pelaksana, mahasiswa dan masyarakat Bersama-sama menanam tanaman obat sebagai apotek hidup di pekarangan rumah masyarakat. Tanaman tersebut dibawa oleh tim pelaksana dari makassar ke lokasi pengabdian desa pacceke, kabupaten Barru.

\section{Hasil dan Pembahasan}

Kegiatan pengabdian kepada masyarakat beriringan dengan adanya kegiatan himpunan mahasiswa Pendidikan biologi (himabio) Universitas Muhammadiyah Makassar yang melaksanakan program kerja pengabdian kepada warga (pandawa) di desa pacceke, kecamatan soppeng riaja, kabupaten barru. Pengabdian masyarakat dengan edukasi pemanfaatan tanaman sebagai apotek hidup dalam mewujudkan masyarakat sehat dan produktif. Kegiatan penyuluhan tanaman obat keluarga bertujuan untuk meningkatkan pengetahuan, pemanfaatan, keterampilan menanam tanaman yang termasuk jenis tanaman obat unggulan sehingga dapat meningkatkan kualitas Kesehatan masyarakat (Harjono et al., 2017). Pk Mini dilaksanakan di Gedung pertemuan desa pacceke kabupaten barru pada hari senin, 5 maret 2018 pada pukul 08.00 - 12.00 WITA. Peserta penyusuhan sebanyak 44 orang yang terdiri dari kepala desa, bhabinkamtibmas, tim PkM, mahasiswa, dan masyarakat desa pacceke yang sempat hadir pada kegiatan PkM ini. 


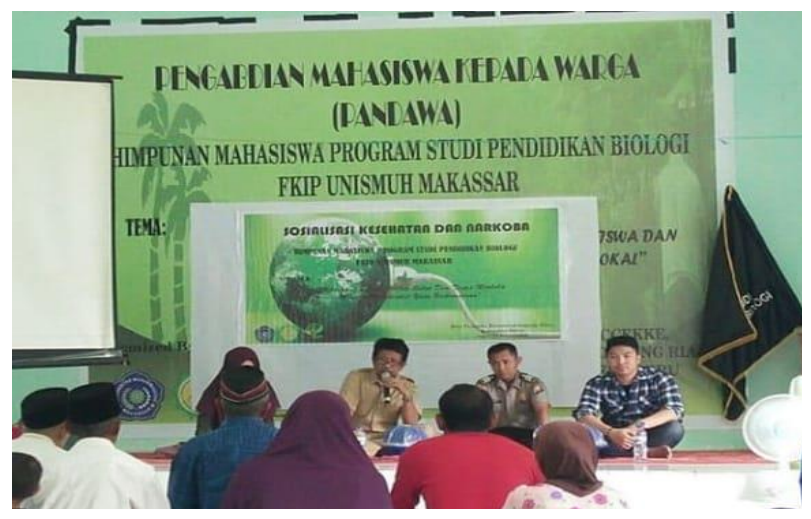

Gambar 1. Pembukaan kegiatan PkM oleh bapak kelapa desa pacceke

Pembukaan kegiatan pengabdian kepada masyarakat yang terlihat pada gambar 1. oleh bapak Muh. Dahlan, S.Si., M.Si kepala desa pacceke beliau sangat menyambut baik terselenggaranya kegiatan $\mathrm{PkM}$ dan kegiatan ini adalah pertama kalinya ada tim $\mathrm{PkM}$ yang datang melaksanakan pengabdian di desa pacceke. kegiatan edukasi pemanfaatan tanaman sebagai apotek hidup merupakan solusi yang diterapkan oleh masyarakat jika memiliki keinginan hidup sehat dan produktif. Keberadaan tanaman apotek hidup di lingkungan tidak hanya menjaga kelestarian lingkungan tetapi juga memudahkan masyarakat dalam mengases obat-obatan tanpa harus memikirkan biaya pengobatan saat terjadi masalah Kesehatan seperti luka akibat kecelakaan, dan diare (Abbas, 2018). Mengingat lokasi desa pacceke ini sangat jauh dari puskesmas untuk berobat dan hanya di kota terdapat fasilitas Kesehatan seperti rumah sakit dan puskesmas yang memadai, jarak sangat jauh ditambah dengan transportasi yang cukup sulit, apalagi jika masyarakat tersebut tidak memiliki kendaraan. Jika memanfaatkan tanaman obat maka akan meminimalkan biaya transportasi dan biaya tersebut bisa digunakan untuk keperluan keluarga yang lainnya.

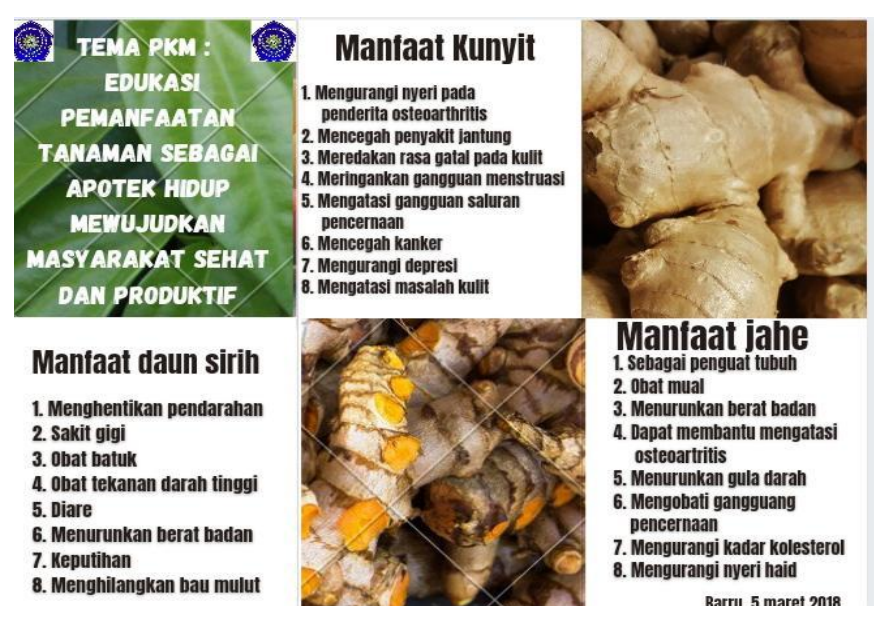

Gambar 2. Brosur materi PkM 
Pada gambar 2, merupakan gambar brosur yang dibagikan kepada masyarakat pada saat kegiatan PkM berlangsung. Edukasi kepada masyarakat dengan menyampaikan secara langsung dan penggunaan brosur yang dipersiapkan oleh tim pelaksana PkM. Penyampaian materi tentang manfaat tamanan sebagai apotek hidup disampaikan oleh dosen Pendidikan biologi Universitas Muhammadiyah Makassar dan pembagian brosur PkM dilakukan oleh mahasiswa. Dalam brosur ditampilkan nama, gambar dan manfat dari tanaman obat. Jadi jika masyarakat lupa manfaatnya dari tamanan obat maka bisa membaca Kembali brosur tersebut. Disamping itu disampaikan pula bahwa tanaman obat bisa langsung dengan membersihkannya terlebih dahulu ataukah dengan cara diolah. Setiap jenis tanaman memiliki cara pengolahan dan manfaatnya masing-masing. Cara pengolahan yakni direbus, dipanggang, diuapkan, ditumbuk, direndam dan digoreng. Ramuan obat yang dihasilkan dapat digunakan dengan cara dioles, ditempel, diminum, dikumur, dipakai berkeramas, dan diapakai mandi (Sambara et al., 2016). Setelah proses penyampaian materi, maka kegiatan dilanjutkan dengan tahap diskusi atau tanya jawab antara masyarakat dan tim $\mathrm{PkM}$ dan masyarakat terlihat sangat antusias dengan penjelasan yang diberikan oleh tim $\mathrm{PkM}$. Pada gambar 3 terlihat bahwa peserta yang hadir dalam kegiatan ini tidak hanya dari kalangan orang tua dan dewasa saja, tetapi juga ada anak-anak yang ikut serta. Hal ini berdampak positif untuk regenasi masyarakat desa pacceke dengan edukasi dini pengetahuan tentang manfaat apotek hidup.

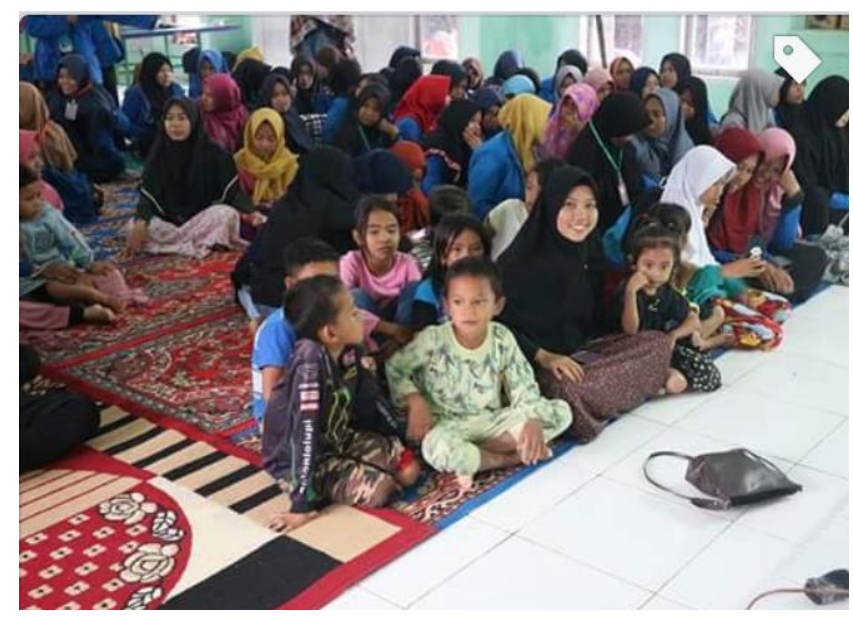

Gambar 3. Peserta penyuluhan $\mathrm{PkM}$

Masyarakat memanfaatkan Sebagian kecil tanah dipekarangan rumah untuk ditanami obat-obatan sebagai keperluan sehari-hari bila ada anggota keluarga yang sakit. pada umumnya masyarakat lebih menyukai mengkomsumsi obat-obat tradisional. Selain karena faktor ekonomi, obat tradisional dianggap lebih aman karena bersifat alami dan memiliki efek samping yang lebih sedikit dibandingkan obat-obat buatan pabrik (Zainuddin et al., 2018). 
Tanaman obat pun tidak kalah cantiknya dibandingkan tanaman hias. Selain dari itu tanaman obat seperti kunyit jika dikeringkan kemudian dibuat dalam bentuk bubuk bisa dijual untuk bahan tambahan makanan. Masyarakat juga bisa memanfaatkan lengkuas, jahe untuk diolah menjadi bumbu instan untuk masakan di hari raya keagamaan atau hari perayaan lainnya. Masyarakat yang berpikiran praktis dan konsumtif akan lebih memilih membeli bumbu instan tersebut.

Pemberdayaan masyarakat di desa pacceke menambah pengetahuan dan keterampilan kepada masyarakat mengenai manfaat dari tanaman yang biasanya ada di lahan pekarangan, khusunya tanaman jahe, kunyit, dan sirih. Tanaman ini mudah untuk dikembangbiakkan dan dikembangkan menjadi obat tradisional bagi masyarakat. Beberapa tanaman obat yang ditanam oleh tim PkM dan masyarakat disajikan pada tabel 1 dibawah ini.

Tabel 1. Jenis tanaman yang ditanam dan manfaatnya

\begin{tabular}{|c|c|c|}
\hline No. & Jenis tamanan & Manfaat \\
\hline 1. & Kunyit & $\begin{array}{l}\text { Mengurangi nyeri haid, mencegah penyakit jantung, meredakan } \\
\text { rasa gatal pada kulit, mengurangi nyeri pada panderita } \\
\text { osteoarthritis, mengatasi gangguan saluran pencernaan, } \\
\text { mencegah kanker, mengurangi depresi, mengatasi masalah kulit, } \\
\text { sakit maag. }\end{array}$ \\
\hline 2. & Jahe & $\begin{array}{l}\text { Sebagai penguat tubuh (imun), obat mual, menurunkan berat } \\
\text { badan, mengatasi osteoarthritis, menurunkan gula darah, } \\
\text { mengobati gangguan pencernaan, mengurangi kadar kolesterol, } \\
\text { mengurangi nyeri haid. }\end{array}$ \\
\hline 3. & Serai & $\begin{array}{l}\text { Mencegah penyakit kanker, mengobati gangguan pencernaan, } \\
\text { manurunkan tekanan darah, gangguan system saraf. }\end{array}$ \\
\hline 4. & lengkuas & $\begin{array}{l}\text { Mencegah dan mengobati tumor, menyembuhkan penyakit } \\
\text { limfa, penyakit reumatik, mencagah radang, mengurangi pusing } \\
\text { pada saat mabuk laut, mengobati diare serta luka dalam perut, } \\
\text { penambah nafsu makan, mengobati penyakit kulit. }\end{array}$ \\
\hline 5. & Sirih & $\begin{array}{l}\text { Menghentikan pendarahan, sakit gigi, obat batuk, tekanan darah } \\
\text { tinggi, diare, menurunkan berat badan, keputihan dan } \\
\text { menghilangkan bau badan. }\end{array}$ \\
\hline 6. & sambiloto & Melindungi hati, menekan pertumbuhan sel kanker \\
\hline
\end{tabular}

Sumber: (Hidayatulloh et al., 2018)

Budidaya tanaman obat tidaklah susah, misalnya jahe hanya mengambil rimpang yang cukup dewasa kemudian memindahkannya pada polybag atau lokasi yang diinginkan. Pada musim kemarau dilakukan penyiraman hanya sekali saja yaitu pada sore hari. Pemeliharaan dilakukan secara manual dengan mencabut gulma atau rumput disekitar tanaman dan hama yang menyerang hanya belalang kecil dan anjing tanah (Sidik, 2014). 
Adapun partisipasi mitra dalam kegiatan pengabdian kepada masyarakat ini adalah menyediakan tempat dan fasilitas pelaksanaan kegiatan pengabdian edukasi pemanfaatan tanaman sebagai apotek hidup untuk mewujudkan masyarakat sehat dan produktif di desa pacceke kabupaten barru. Dimana masyarakat sangat antusias mengikuti kegiatan ini sampai selesai. Pada akhir tahapan kegiatan pengabdian kepada masyarakat ini dilakukan monitoring dan evaluasi oleh tim PkM, pada hari selasa tanggal 6 maret 2018. Hal tersebut dilakukan untuk mengetahui ada atau tidaknya peningkatan pengetahuan dan keterampilan masyarakat terkait edukasi yang telah diberikan. Tim PkM melakukan monitoring terhadap tanaman apotek hidup yang di tanam di pekarangan masyarakat. Alhasil tanaman tersebut sudah disiram pada pagi hari dan ada juga masyarakat yang membuatkan pagar-pagar dari bambu agar tanaman tersebut tidak diganggu oleh hewan.

\section{Kesimpulan}

Berdasarkan hasil kegiatan pengabdian masyarakat dengan edukasi pemanfaatn tanaman sebagai apotek hidup mewujudkan masyarakat sehat dan produktif di desa pacceke dapat disimpulkan bahwa peserta sangat antusias dengan pelaksanaan kegiatan ini. Dengan melestarikan tanaman obat di desa pacceke dapat membuat pekarangan rumah menjadi lebih bermanfaat, dan masyarakat juga secara tidka langsung telah melakukan penghematan dari segi perekonomian keluarga. Untuk kegiatan penyuluhan selanjutnya, disarankan sebaiknya menambah tanaman apotek hidup yang di bawa kelokasi $\mathrm{PkM}$ sehingga informasi yang diperoleh masyarakat lebih banyak.

\section{UcapanTerima Kasih}

Tim penulis mengucapkan terima kasih kepada kepala desa dan staf desa pacceke, kecamatan soppeng riaja, kabupaten barru yang telah memfasilitasi tim pelaksana $\mathrm{PkM}$ sehingan kegiatan ini terlaksana dengan lancar. Dan kepada seluruh mahasiswa dari Himabio Pendidikan biologi Universitas Muhammadiyah Makassar yang telah membantu sampai tahap evaluasi dari kegiatan PkM ini.

\section{Referensi}

Abbas, A. (2018). Pemberdayaan Siswa SD dalam Penanaman Apotek Hidup di Lingkungan Sekolah. Prosiding Artikel Seminar Nasional Pengabdian Masyarakat (SENIAS) 2018, 1 5. https://prosidingonline.iik.ac.id

Basuki, K., Rosa, N., \& Alfin, E. (2020). Membangun Kesadaran Dini Masyarakat Dalam Membangun Desa. JMM Jurnal Masyarakat Mandiri), 1(2), 75080. 
https://doi.org/10.22216/jen.v1i2.984

Dewantari, R., Monika, L., \& Nurmiyati. (2018). Jenis Tumbuhan yang Digunakan sebagai Obat Tradisional Di Daerah Eks- Karesidenan Surakarta. Bioedukasi, 11(2), 118-123. https://doi.org/10.20961/bioedukasi-uns.v11i2.19672

Harjono, Y., Yusmaini, H., \& Bahar, M. (2017). Counselings the Utilization of Medicinal Plants and Planting of Medicinal Plants in Kampung Mekar Bakti. JPM Ruwa Jurai, 3, 16-21. https://doi.org/10.23960/jpm.v3i1.1933

Hidayatulloh, A., Mahandika, D., Yuniantoro, Y., \& Mudzakir, M. D. (2018). Pembudidayaan Tanaman Apotik Hidup Guna Meningkatkan Perekonomian Masyarakat. Jurnal Pemberdayaan: Publikasi Hasil Pengabdian Kepada Masyarakat, 2(2), 341-346. https:// doi.org/10.12928/jp.v2i2.457

Nugraha, S. P., \& Agustiningsih, W. R. (2015). Pelatihan Penanaman Tanaman Obat Keluarga (Toga). Jurnal Inovasi Dan Kewirausahaan, 4(1), 58-62. http://journal.uii.ac.id/ajie/article/view/7896

Nurniswati. (2015). Tanaman Obat Keluarga (Revisi). Parapemikir: Jurnal Ilmiah Farmasi, 3(09), 1-3. https://books.google.com/books?id=fAbu7I9LqXsC\&pgis=1

Sambara, J., Yuliani, N. N., \& Emerensiana, M. Y. (2016). Pemanfaatan Tanaman Obat Tradisional Oleh Masyarakat Kelurahan Merdeka kecamatan Kupang Timur 2016. Jurnal Info Kesehatan, 14(1), 1113-1125. http://jurnal.poltekeskupang.ac.id

Sidik, R. F. (2014). Pembelajaran Ilmu Pengetahuan Alam Tematik Berbasis Tanaman Obat Keluarga (TOGA). Jurnal Pena Sains, 1(1), 67-74. https://doi.org/10.21107/jps.v1i1.1331

Zainuddin, A., Mayanti, T., \& Anshori, A. J. (2018). Pengenalan Apotek Hidup dan Media Penanaman Hidroponik Kepada Ibu-Ibu PKK Di Desa Sayang Kecamatan Jatinangor. Jurnal Pengabdian Kepada Masyarakat, 2(6), 1689-1699. https://jurnal.unpad.ac.id/pkm/article/view/20263 